According to what we read and hear, Eddyites are following in the same footsteps. If they aid in promoting temperance in alcohol and tobacco they will do good, but if they profess to cure disease by their methods or to assert that there is no such thing as real pain, then we are justified in calling them quacks. How can quackery be checked? In the first place, medical men must not practice quackery themselves, for it is too true that it exists inside as well as outside of the profession. Then it is important to individualize in treatment, so that patients may reap the greatest benefit, while careful and accurate diagnosis and prognosis will help to guard against disappointment. In Great Britain, he said, there is no legislation against quackery. The government receives $\$ 1, \mathbf{5 0 0 , 0 0 0}$ annually from the licenses and stamp duties on the sale of "patent medicines." Many "patent medicines" in no way comply with the law requiring that they must be genuine original inventions, and that a complete description of them must be filed at the patent office. In both France and Germany there is at present a great deal of agitation in favor of greater stringency in dealing with quackery and stricter supervision of proprietary remedies. In conclusion he said that it is important to realize the responsibilities resting on those entering on the practice of medicine, both in exercising the sympathetic faculty and in cultivating friendly intercourse with patients of all classes.

The Choice of a Holiday.-The summer holiday is usually believed to be a season for recuperation and for renovation, says the Medical Press; a time when the jaded tissues are able to cast off effete products of over-activity, and to lay in a store of energy for the coming months. If the holiday is to be this, and not a mere new-sensation-hunting performance, the choice of the place in which it is to be passed is of great importance. To go to a seaside town or a mountainous district simply because a friend has gone thither and liked it, is not to plan one's holiday scientifically; which is another way of saying that for a holiday to do one good, the selection of the place where it is to be passed must be determined by the necessities and conditions of the individual. To many delicate women strong breezes and bracing air cause exhaustion and prostration, while, again, the relaxing atmosphere of some sheltered resorts sends the young and vigorous home but little the better for the trip. Especially needful is the exercise of care in advising old people as to their change. To send elderly and overworked men to the high altitudes is to cause them some not inconsiderable danger of apoplexy, and if they are asthmatic or subject to chronic bronchitis the rarified air of high mountains may cause ruinous damage to lungs and heart. Climatology as an exact science is yet in its infancy, but it is sufficiently advanced for a well-educated medical man to be able to advise wisely on the choice of a holiday resort, and people generally would do well to consult their professional attendant before booking rooms a month or six weeks ahead.

\section{Travel Notes}

(Continued from page 612.)

DISEASES AND HOSPITALS OF PORTUGUESE EAST AFRICA.

NICHOLAS SENN, M.D.

Professor of Surgery in the University of Chicago and Professor and Head of the Surgical Department of Rush Medical College. ciricago.

Portugal has a claim on Africa by the right of discovery, and in the apportionment of the country by the great powers of Europe she has held her own and her flag floats in the breeze of both coasts. Her possession on the east coast consists of a long, narrow strip of land, extending from German East Africa southward to Tongoland and including the Island of Mozambigue. The country is only thinly settled, owing to the prevalence of malaria, which makes it dangerous for Europeans to make their homes anywhere on the vast stretch of lowlands, where the soil is most productive. The Portuguese have to contend here, like their neighbors, the Germans, with all kinds of tropical diseases, notably malaria and dysentery.

\section{MOZAMBIQUE.}

Boys who study geography are sure to preserve the names of certain places, cities, rivers, capes, islands, etc., in their memory long after they have forgotten the exact boundaries of faniliar states and countries and the length and course of well-known rivers. The names that have clung to me ever since I left the hard benches of the country schoolhouse were Tahiti, Zanzibar and Mozambique. I have now seen all of these places and none of them has presented the aspects which would correspond with the mental picture that I had drawn of them. Of these historic and interesting islands, Mozambique was the most disanpointing. I had dreamed of a larger island with volcanic mountains and valleys green with luxuriant tropic vegetation, noble wild animals, bircls of plumage, monkeys traveling over land by leaping from tree to tree, using their long mobile tails as an additional and most important prehensile limb; a very ancient city, with streets so narrow that two persons would find it difficult to walk abreast. Imagine my surprise when we sighted an island in the small Mokambo Bay, almost flling the same and only three miles long and on an average not more than three-quarters of a mile wide, flat and sandy, a Jittle oasis in the Indian Ocean, hugging the mainland closely, as if in fear of being engulfed by the sea, with here and there a timid palm raising its feathery erown above the plain, square, white, two- and one-story flat-roofed houses. As we came nearer a fleet of East Indian dhous was seen anchored in front of the landing-place, as well as a small gunboat with four guns, flying the Portuguese flag. The official inspection by the health officer and the custom-house officials

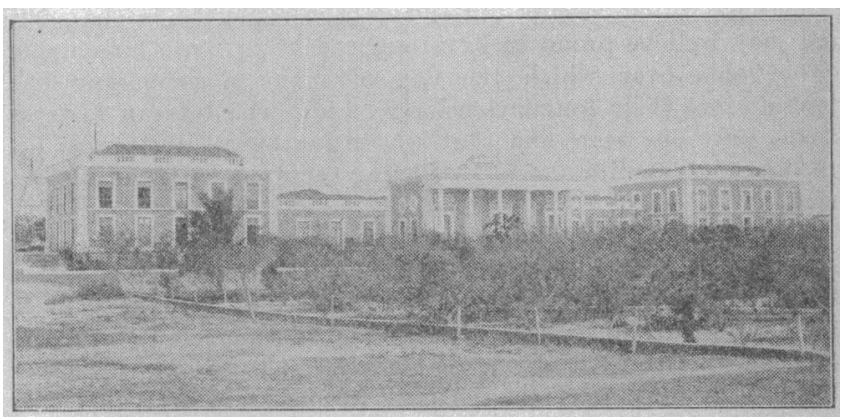

Military and Civil Hospital Mozambique.

was over in a short time, and we at once went ashore in a rowboat to utilize the few hours to the best advantage in seeing the sights of the city. Our haste proved useless, as there was not much to be seen. There are neither horses nor any kind of traction or riding animals in the eity, and the only conveyance obtainable for those who can not or are not willing to walk is a jinrikisha. The blacks here make as good jinrikisha men as the Japanese, who are experts in this kind of getting about.

Mozambique, a city of 7,000 to 8,000 inhabitants, has no hotel and no regular restaurants. The city has many winehouses, but has made no satisfactory provisions for the hungry stranger, who is glad to return to his ship when mealtime comes. The streets are in excellent condition, but sidewalks are cither very narrow or entirely wanting. A few little parks with scrubby, hardy shade-trees relieve the eyes, which everywhere else see nothing but sand. Trees and flowers show by their puny appearance their burning thirst for water. All the shops are small, containing only what the people most need. The blacks here are very independent in their bearing, showing very plainly that they have the upper hand in the management of the affairs of the city. The small military force stationed here, as well as the police, is made up exclusively of blacks under the command of white officers. We visited the market and saw what is brought over from the nearby 
mainland and what the sea furnishes. Several negro women, the most ugly and vicious-looking that we have seen so far, who were seiling palm wine, did the best business. The wine in large earthen jars was still fermenting and bubbling. Two cents hought a gourdbowlful, holding about a quart. Two such doses make the black happy for the balance of the day. The behavior of the Amazons who dispensed this stuff was enough to show that they had done their share in emptying their vessels. We tasted this palm toddy. It was cool and pleasant to the taste, slightly sour and had some of the pungency of dry champagne. There were fish, fresh and fried, bananas, thin, narrow strips of bread fresh from the stove, served hot on banana leaves, cocoanuts, papaya, manihot roots, raw and boiled, several kinds of capsicum, small bundles of split firewood, etc., all articles for which only the natives have use. What little is left of the island outside of the city is a sandy descrt.

The sight that I presume every visitor who lands here goes to see is the old fort of St. Sebastian. It is this ancient fort, with its grim, high walls blackened with age, which is seen first when the city comes in view. The building of this fort dates to the time of $\mathrm{Da}$ Gama, when he sailed along the east roast of Africa in search of a new waterway to East India. The fort is built on a narrow spit of the island, covering its entirc width, and the thick, solid walls rise from the sea on three sides. It is kept in good repair and now serves as a barrack for the soldiers. The walls rise high above the inner even court, where the black soldiers are drilled in the art of war. On the top of the rampart facing the sea the portholes a re occupied by ancient cannons of prodigious size, mounted on (arriages with rickety wooden wheels. These fearful engines of war probably have never spoken. but were ready centuries ago to spit fire and destruction had any foreign power made an attempt to gain possession of the little island. This ancient citadel, with its historic guns, would be helpless against a single modern battleship, but it has been respected in the past, and inay well be proud to have outlived other more formidable strongbolds over which the flag of many a conqueror has floated since their foundations were laid. The veteran fortress shoivs only one sear, and that was made by an accidental explision of dynamite and is now being repaired with the utmost care.

The Roman Catholic church rules here supreme. The cathedral is a very modest church and the other two churches show no greater pretensions. The church has been prudent in the expenditure of money. Schools had to be erected and maintained. In the yard of one of these schools we saw the black children at play after the morning lessons were over, and they were indeed a eheerful, happy lot.

Portuguese and natives live on the best of terms throughout this possession. There is no conflict nor even manifest dissatisfaction here. The government treats its black subjects leniently and with much consideration. Experience has shown that the negro can be led, but not forced, to do a thing which comes in conflict with his own ideas of right and justice; he is a lamb when led, a mule when forced. Only two Germans and nine Englishmen live in the city and only a very few East Indians and Arabs. Mozambique has its own postage stamps. and the money in circulation is coined for Portuguese East Africit.

\section{MOZAMBIQUE MILITARY AND CIVIL HOSPITAI.}

I have never been in a colony or protectorate where the native sick are treated with so much consideration and are taken care of so well as in Portuguese East Africa. The colony has no separate hospitals for Europeans, as in British and in German East Africa, but white and black live under the same roof and receive the same care. We miss here the superb, rostly buildings set aside exclusively for the care of Europeans, such as I have described in speaking of British East Africa and German East Africa. Of all nations owning or protecting foreign lands, Portugal has had the longest experience and has learned how to treat alien subjects without causing friction. The sentiments of the people are considered in formulating rules for their government. Perhaps the most important secret of Portuguese peaceful colonial rule is found in the fact that the line of division between the officers and the people of the home government and the blacks is not as sharply drawn as in the colonies of other nations. It is the conspicuous preference given to the whites that stings the blacks, the rightful owners of the soil. The Portuguese have learned this by a long experience and shipe their rules accordingly.

I can give no more striking example of Portugal's lenient foreign policy than by a brief description of the Mozambique Military and Civil Hospital, which answers to the construction and administration of every other government hospital in Portuguese East Africa, of which there are several. In the first place, these hospitals are built and, at least in part, maintained by the government, and are in charge of Portumuese military surgeons, especially trained for their manifold functions. In the second place, the sick in the colony, white and black, officers, government officiale, soldiers, policemen, rich and poor, educated and ignorant, old and young, men, women and children, are under the same administration. While the whites are given preferences, these do not stand out in the eyes of the natives in such sharp lines as in the hospitals of most of the other colonies. The same doctor who treats the whites attends to the blacks; the same sisters who nurse the Europeans take care of the natives. The difference, if any, is in degree, not in kind, and it is considerations like these that the negro knows how to appreciate.

The hospital was built twenty-five years ago, and at that time it would have compared well with most of the hospitals of Europe and America in construction and equipment. Its architecture is decidedly Spanish in style. Like all other substantial houses on the coast of Africa. it is built of rough stones of coral rock, with a heavy inside and outside coating of eement. The two main buildings are two stories high and serve for private rooms of patients of the first class, small wards for the second class, directors' apartments, pharmacy, storcrooms, chapel and dormitory for the sisters. The large wards for patients of the third class and all charity cases are in one-story pavilions, the blacks in separate wards. The firstclass patients pay $\$ 2$ per day, the second-class 75 cents and the thirä-class 25 cents. Jight and air flood every room of the handsome, well-arranged complex of buildings, which on one side face the principal street of the city and park and on the other the harbor. As the eity of Mozambique must rely on rain for its water supply, each house has its own cistern. The hospital has two immense underground cisterns, with a total capacity of 600,000 tons, which furnish an abundance of pure, cool drinking water. These cisterns are located between the pavilions. The sprees between the main buildings and the wing are paved with tlat stones and are kept as clean as the mosaic tile floors in the interior of the buildings. The hospital has 200 beds, and during the rainy season, when malaria is most prevalent, its full capacity is heavily taxed, but at the present time the number of patients is only eighty. The pharmacy is in charge of a competent druggist and is well stocked, and the two large storerooms are well supplied with medicines, dressing materials, becding, etc. The operating room is small but well constructed and equipped for modern surgical work Fery little surgery is done here, as in all other East African hospitals, on an average not more than two operations a day, and most of these are minor operations. A Roentgen apparatus has recently arrived and will be put in operation as soon as electric power can be secured, and then it will be the first one to be employed on the East Coast of Africa. Dr. Francisco Maria do Amaral is the director of the hospital and is assisted by three other military surgeons. He speaks English fiuently and has kept pace with the modern progress in medicine and surgery. He took great pains in explaining the details of the hospital work and in showing the interesting cases then under treatment.

Eight Catholic sisters have cliarge of the nursing and they are issisted by orderlies and native helpers. The average number of patients during the year is about 2,000. The patients come from all parts of the province of Mozambique. Dr. Amaral has been stationed here for a long time and has never seen a case either of carcinoma or appendicitis in the black. The same holds true of the Eskimos of the far north, as I 
ascertained last summer when I went to Etah, the most northern habitation of man. It seems, then, from the geographical limits of these diseases that civilization with its complicated dieteties is responsible, to a large extent, for their prevalence in Europe and the United States.

diseases of THE Province of mozambique.

From information obtained from Dr. Amaral and from scanning over the last report of the Service of Health (Relatorio de Servico de Saude do Provincia de Mozambique Estatistica Mospitallare Anno 1994) for 1004, a government publication replete with painstaking, accurate statistics, I gained a fair insight into the prevailing diseases of this part of Portuguese colonial Africa. I have already mentioned that $\mathrm{Dr}$. Amaral had never seen during his long residence here a case of carcinoma or of inflammatory disease of the appendix in the negro. There is a little laboratory in the hospital where bacteriologic studies are made and pathologic specimens are exam. ined microscopically, so that we have reason to believe that these diseases were not overlooked. In the report $I$ find, under the head of "Cancer and other Malignant Tumors," three deaths reported from Lorenzo Marques, one of which was from sarcoma of the breast, one from intestinal neoplasm, and in one, a negro, 17 years of age, the cause of death is given as cancer of the pancreas, the diagnosis having been confirmed by autopsy.

\section{TOTAL MORTALITY.}

The total mortality of the province for the vear was 1,222 . Of this number there were 202 Europeans, 125 Asiaties, 892 Africans and 4 white Americans. The list includes 6 intrauterine deaths, 973 males and 249 females, and of these 500 diad in different hospitals and 722 ontside of the hospitals.

\section{IIOSPITALS.}

The nine hospitals of the province are located at Lorenzo Marques, Mozambique. Quclimane. Imhambane, Chinde, Chibuto, Angoche, Tete and Mossuril. The total number of patients treated in these hospitals for the year was 9,055 , of which $4,14 i$ were military and 4,914 civil ; 8,213 males and 822 females. Of this large number of hospital cases there were only forty-two children below the age of 5 years, a figure showing again and most conclusively that the blacks have little use for hospitals in the care of their sick children.

In visiting the hospitals of the coast I was struck by the smali number of children under treatment. Most of the children I saw were not ill, but accompanied their sick mothers.

\section{MA.LARIA.}

Malaria here, as well as everywhere else on the coast, is the prevailing disease, and the patients suffering from this disease fill the hospitals to overflowing during the rainy season. In the nine hospitals 3,661 eases, or more than one-third of the whole number of patients, were treated for malaria, with eighty-three deaths, the mortality varying with the hospital, being lowest at Chibuto, 1.2 per cent, and highest at Chinde, 6.3 per cent. Malarial diseases are classified as follows:

\begin{tabular}{|c|c|c|c|}
\hline ittent fey & $\begin{array}{l}\text { Number of } \\
\text { Cases. }\end{array}$ & Deaths. & $\begin{array}{r}\text { Per- } \\
\text { centage }\end{array}$ \\
\hline Remi & 3,577 & $\frac{1}{1}$ & 0.03 \\
\hline fev & $\begin{array}{l}19 \\
39\end{array}$ & 26 & $\begin{array}{r}5.3 \\
66.6\end{array}$ \\
\hline & 171 & 43 & 25.1 \\
\hline Malarial cachexia & 175 & 12 & 6.9 \\
\hline
\end{tabular}

Among the malarial patients the whites figure largely in excess of the blacks, their total number being 3,175 , with 67 of the total number of 83 deaths. Next to the whites the halfcastes suffer most frequently from the grave forms of malaria and contribute most to the mortality list.

TREATMENT OF MAIARIA BY SUBCTTANEOUS INJECTIONS OF QUININ.

Dr. Amaral is very partial to this method of treatment in all grave forms of malaria. The preparation he uses is a solution of half a gram of quinin. kept ready for instantaneous use in a glass capsule drawn out on opposite sides and sealed by heating the ends. The hypodermic needle is charged by breaking off one of the ends, when the fluid is aspirated directly from the capsule and is at once injected under strictest aseptic precautions. If the case is severe he makes the injections morning and evening until the disease is under control. This way of administering quinin would seem to recommend itself in all grave cases, more especially in military practice.

SMALLPOX.

This disease appears to visit the colony almost every year, but on the whole is on the decline. Only 118 cases were observed during the year, of which the disease proved fatal in six. During the year, 4,590 persons were vaccinated, and of this large number there were only 32 whites and an equal number of half-castes. At Queīimane alone 2,162 negroes were vaccinated.

\section{DYSENTERY.}

During the whole of the year, 224 cases of this disease entered the hospital for treatment. Of this number 98 died, a very large mortality. Of the 83 whites, only 8 died, showing that the mortality from the disease is greater among the blacks than the whites, probably in consequence of neglect and improper diet, as well as for the reason that they do not apply for treatment in time. The disease is more frequent in the country than the cities, and its greater prevalence there is attributed by the physicians to the drinking of polluted water and the eating of improper food.

\section{TUBERCULOSIS.}

Pulmonary tubcrculosis is on the increase on the coast where the blacks are brought in contact with the Europeans. The numiver of deaths from this disease in the province of Mozambique for 1904 was 185 , divided among the different nationalities as follows: Europeans, 24; Asiatics, 26; Africans, 34, and 1 American. Here for the first time $I$ found mention in the reports of cold abscesses and general tuberculosis occurring in the natives on the coast.

$$
\text { SYPIILIS AND VENEREAL DISEASES. }
$$

The presence of venereal diseases is well shown in the following table for the year 1904:

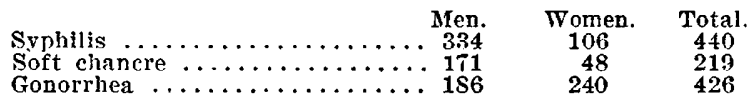

l'his table gives by no means the whole number of venereal discases, as many of the blacks, especially the women, do not apply for treatment.

\section{PNEUMONIA.}

This disease is very fatal. Of the 40 cases treated in the hospitals, 18 died, a mortality of 45 per cent.

$$
\text { DISEASES OF DIGESTIVE ORGANS. }
$$

These diseases are grouped together under the head of diarrhea and enteritis. The total number is given at 178, which, of course, included only the grave cases. Of this number 67 were Europeans, with 5 deaths. Of 321 cases of disease of the stomach none resulted in death.

\section{SLEEPING DISEASE.}

This disease has never been known to originate in the city of Mczambique. Two deaths from it are recorded in the report. One of the patients was a native soldier, who contracted the disense on the coast; the other was a negro, who came affected with the disease from Angola, Portuguese West Africa.

\section{LEPROSY.}

The number of lepers is given at 30, distributed over the province as follows: Lorenzo Marques, 19; Mozambique, 1; Inhambane, 9, and Tete, 1 . Lepers are not admitted into any of the hospitals. Dr. Amaral has recommended to the governnent the establishment of a home for these unfortunates, who are now entirely neglected and have to depend on their relatives and friends for support and care.

\section{DISEASES OF THE SPLEEN.}

Considering the prevalence of malaria in the province, the number of cases of enlargement of the spleen, as given in the report, is remarkably small, only 29 ; of these, 24 were whites, 1 yellow and 4 blacks. The negroes are very resistant to chronic malarial poisoning and are very rarely affected with enlargement of the spleen as compared with the whites. 


\section{BEIRIBERI.}

This disease was observed 18 times during the year. I.ormuzo Marques furnishnd is cases, Mozambique 1 and Chile 2. Of this number, $\overline{5}$ died.

\section{RIIEUMATISM.}

Of this disease there are recorded 370 cases, 230 acute and 120 chronic, with a mortality of 4,2 from the acute and 2 from the chronic form of the disease.

We miss in this enumeration of diseases carcinoma, with the exception, perhaps, of a doubtful case, also appendiritis and yplucid fever. Strangely enough, typhoid fever has not as yet gained a foothold on the soil of the east coast of Africa, although the sanitary conditions in many places are such as wontil seem favorable to the growth and spread of the bacillus of the disease. Neither is there mention nuade of the most common diseases of childhood: measles, diphtheria, scarlatina and whooning-cough. Tweive cases of cerebrospinal meningitis were observed, with a mortality of $\overline{5}$. Considering the severity of the climate, the prevalence of malaria and its many complications and the doubtiul water supply of the people living in the interior, the general mortality could not be callerl excessive. The national vice of laziness and the absence of manufacturing establishments of any importance account for the small number of injuries, only 449 cases.

\section{BEIRA.}

Brira, at the mouth of the Pungwe River and a short distance south from the delta of the great Zambesi River, is the most important port of Portuguese wast Afriea. Tho little city is lneated on a narrow, sandy strip of land between the month of the Pungwe River, which serves as an excellent harbor, and Mazangzani Tay. The terminus of the Rhotesia Railroad here adds murb to the commercial and shipping importance of the rity. Most of the houses are solid two-story lorick and cement buildinas, with tile or enrugated iron ronfs. There are only two or three horse vehicles here. The principal strect bicects the city and has in the midlle a narrow-comige track of the man trolley cars, a great convenience for getting shout the far-spun-out eity and for the transfer of freight. Most of the professional and business men have their own private enr and their own man to push it. Two peranns can sit comfortably side by sirle, and in case of need a third $\cdots n$ be sandiriched in between. There are only a few short sirlewalks in the city, so that most of the walking must be rone by wading ankle-deep in the lonse, lot sand. At the time of our visit the heat was very opnressive. There are a few large stores, in which almost everything is kept which is most needeit, but at prices which stun the visitor. Among the several liotels the Sarop and Queen's Hotel are the best. The table of the former, for such a place as this, is excellent. and the rooms are large and airy. A bank, several steamship offices and the railway cffice handle the bulk of the money. The r.rison, in the heart of the business part of the citv. is a most unique building. It is small and has all the appearances of a neat chapel if it were not for the strong iron bars of the high, narrow and numerous windows. The city is only ten rears old. The next eity on the const south from here, Sofula, was for several hundred yents the port. The good harbor here made it necessiry to transfer business and shipping to this place. A few kinds of hardy trees, cocoa palms, euclyntus, acacia, wild a!mond, etc., have been planted and seem to thrive in this dry, hot, sandy soil. Most of the natives are kaffirs, black as conl and fine specimens of physical development and muscular strength. Most of the laborers wore nothing but a loin cloth, and this in most instances was none too wide.

Beira has an unenviable reputation as a fever nest. $\mathrm{Mr}$. Bryce, who visited this place before the railroad was completed, made the statement that no white man could remain three consecutive days anywhere between Beira and the inland mountain platea and escape an attack of fever. All the white people who have lived here for several years have had their good share of malaria. I examined a number of negro children and they all had the prominent abdomen seen in children living in malarial districts, and in all of them the enlarged spleen could be felt several inches below the costal arch. All the white women I saw were pale, emaciated and evidently much enfeebled, as was shown by their drawn faces and languid walk. Their little children were in the same condition. Several of the sisters in the hospital were very anemic, poor in flesh and none too strong for the arduous duties in care of the sick in their charge.

Bein is one of the hottest places on the coast. The hottest months are December and January. At this time the thermometer not infrequently registers $120 \mathrm{~F}$. in the shade, and $\mathrm{I}$ was tola that egos placed on the hot sand and exposed to the burning rays of the sun were cooked hard in a short time. Throughout the year it is disagreeably warm from 10 o'ciock in the molning until 4 in the afternoon, and during this time the pcople remain in their houses and very little work, if any, is done. Iiven the postoffice officials have their midday siesta. 'The mallimes are so arranged that they do not interfere with the working hours. The first plain breakfast early in the morning is followed by a second one at $11: 30$ a.m., which is a substintial meal. Dinner is served late in the evening.

\section{BEIRA GOVERNMENT HOSPITAL.}

Beira has only one hospital, which was built and is main. tained at government expense. It is beautifully located in park-like groinds and faces the principal street on one side and on the other side the bay. The hospital was built ten rears ago at a cost of $\$ 25,000$ and has room for sixty patients. At prescrit, the conlest and healthiest season of the year. the number of paticnts does not exceed thirty, and most of these are enffering from malaria. The government physician, Dr. Jose Aranjo de Lacerda, is in charge of the hospital and the nursing is under the care of five Sisters of St. Francis. The hospital consists of two one-stcry brick and cement barracks. one for the whites and the other for the blacks. The cots in the litter building are the narrowest I have ever seen, hardly eighteen inches in width. The framework is made of iron bars, on which a piece of canvas is stretched. Each cot is supplied with two white sheets and a pillow, and the patients on these, the narrowest of all beds, appeared to be comfortable. Sinple and p?ain as these beis are. they must seem a luxury to the backs, who know no softer bed than a mat on the bare ground. In lic cottage for the whites are a number of plainly fur. nished but very comfortable private rooms, for which a charge of $\$ 5$ a day is made. In the little wards the second-class patienta pay $\$ 1$ a day. Few of the negroes are able to pay anything, and as this class of patients during the year is large they become a heary tax on the firancial resources of the hospital.

I saw and examined here patients suffering from malaria in all its multitudinous forms. In the acute form the temperature curves were nearly the same in all cases. A chill, followed by a temperature of $40.8 \mathrm{C}$., then under quinin treatment a speedy fall to normal. Dr. Lacerda, like Dr. Amaral, relies largely on tipe subcutaneous use of quinin in doses of seven and one-ba]f to fifteen grains, administered once or twice during twenty-four hours. In some cases quinin is given at the same time by the mouth, and to prevent its being ejected by vomiting it is mixed with pulverized gentian. If, as is often the case. a light icterus makes its appearance, three grains of calcmel are given, followed by a saline cathartic. In the beginning of the atteck evaporating camphorated lotions are employed to reduce the high temperature, and phenacetin is given to relieve the intense headache. In chronic cases arsenic is frequently used in combiration with quinin. In the pernicious form of malaria the system is saturated as quickly as possible with quinin. given subcutaneously and by the stomach, so that the patient receires at least forty-five grains during the first twenty-four hours. One case of blackwater fever was under treatment and well on the way to recovery. Beside malaria, I found in the ward for the natives a rase of advanced pulmonary tuberculosis, parenchymatous mammitis in a syphilitic woman, tropical abscess in a bor about 12 years old and a case of chronic dysentery. In front of this ward we saw squatting on the sand an old negro, a mere skeleton, evidently the subject of some men tal icrangement. He refused to eat rice, meat and other nutritious articles of the hospital diet, but made his evening meal of black coffee and a piece of bread, which he tore in pieces and 
moistened in the black fluid. Dr. Lacerda has never seen a case of carcinoma or appendicitis in the neyro, and believes that these diseases do not affect the race. Typhoid fever is unknown here.

The drinking water is obtained from a subterranean cement cistern. in which the rainwater is collected. For other purposes the water is obtained from a well on the hospital grounds. The sisters live in a separate building. In another completely detached small building are the bathrooms and closets. The wash-house is in an open shed, in which there are a number of large cement tubs, in which the native employes do the wasing by hand in the customary primitive way. Provision for postmortem is male in a small morgue, where two large slab tables were waiting for the next victims, who will not be long in coming. The hospital has 'a large dressing-room, where the outdoor patients are attended to and where the few operations are performed, as there is no room set aside for this special purpose. Dr. Lacerda said that during the year not more than two capital operations are performed. From all I have seen the east coast of Africa is no place for surgery. The physician who his a thorough knowledge of malaria and its treatment, and is well-grounded in the diagnosis of syphilitic affections and the rational use of mercury and potassic iodid, and who can treat most successfully blennorrhea without leaving an of its many complications, is the man most needed, and he wiil meet with the greatest success financially, and in gaining a permanent and widespread reputation, for malaria and syphilis are the white pests of the coast.

(To be Continued.)

\section{State Boards of Registration}

\section{COMING EXAMINATIONS.}

Wroming State Board of Medical Examiners, State Capitol, Cheyenne, Septeuber 5. Secretary, s. B. Miller, Laramie.

Massaciusetrs Foard of Registration in Menicine, State Ilouse, Roston, Sentember 11-12. Secretary, Edwin B. Ilarvey, Joston.

Iowa State Board of Mfedical Examiners. Capitol Building, Des Moines, Septemier 11-13. Secretary, J. F. Kennedy, Des Moines.

OKLatroma Roard of Medical Examiners, Guthrte, September 25. Secretar'y, J. IV. Baker, Enid.

New York Boards of Mediral Examiners, Albany, September
25-28. Chief of Examining Division, Charles F. Wheelock, Albany.

Connecticut July Report.-Dr. Charles A. Tuttle, secretary of the Connecticut Nledical Examining Board, reports the written examination held at New Haven, July 10-11, 1906. The number of subjects examined in was 7 ; total number of questions asked, 70 ; percentage required to pass, 76 . The total number of candidates examined was 37 , of whom 28 passed and 9 failed. The following colleges were represented:

\section{College.} PASSED.

Year.

Per

Yale University $\ldots \ldots \ldots \ldots \ldots \ldots$ (1905) $81 ;(1906) 78,83.2,8.7 .2$

University of Maryland $\ldots \ldots \ldots \ldots \ldots \ldots \ldots \ldots \ldots(1906)$.

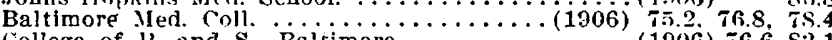

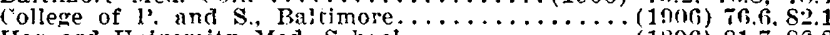

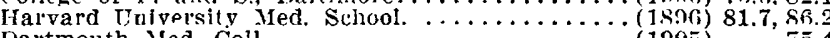

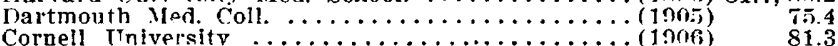

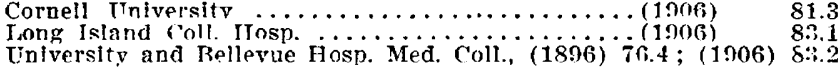

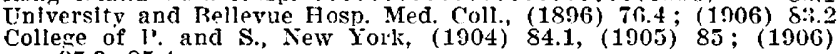

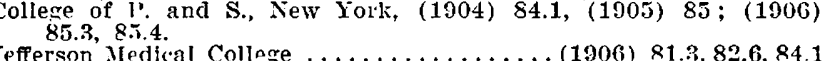

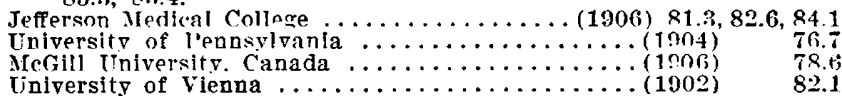

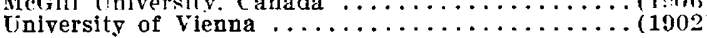

FAILED.

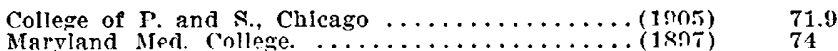

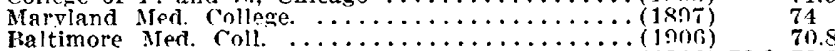

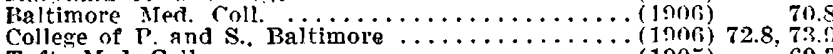

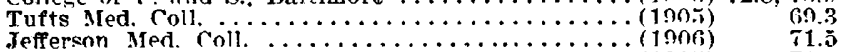

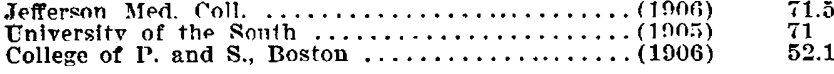

The following questions were asked:

PRACTICE, PATHOLOGY AND DIAGNOSIS

1. Ftiolngy, symptom and tregtment of cholera infantum. 2 Contrast the svmptoms of exonhthalmic goiter and myxedema. 3 Give the symntoms and patholocy of each of the three staces in
acute lobar pneumonia. 4. Different:ate between scarlatina, rubeola and rubella: (a) Lefgth of period of inclubation of each. (b) Symptoms of the stages of : 1. Invasion: 2, eruption; 3, desqua-
mation. (c) l'rincipal complications and segutelis. F. Give the mation. (c) l'rincipal complications and sequelie. S. Glve the greatest intensity and direction of transmission of the foilowing lent murnurs: (a) Aortic diastolic. (b) Mitril systolic. 7 . Cantes of puimonaly edema. 8. (auses of infiantile convilsions. C. Define aphasia avd give its diferent forms and the seat of the lesion of each. 10. 'Treatment of eczema both constitutional and local.

1. Nescribe the red blood corpusetes, (a) as to origin and fate, (b) form. (e) size (d) number. (e) function. 2. What are the agents concerned in the cirentition of the biood? 3. Sescribe normal pulmonars sounds. 4. hefine primary anenia, and how ts it distinguished from that known as secondaly? (o. That and Where are ryonners ghands? (b) Perer patehes? (c) The funcurinary secretion: (b) Ihat is the most important incredient in urine, and what does it represent: 7 . State the function of $(a)$ tise vas deterens, (b) the vesiculie seminales. (c) the prostate gland. 8. Classity nervons functions. (b) What are reflex centers? (c) What are antomatic centels? S. Throigh what channels and by What processes are the eald products of digestion conveyed to the klond? 10. Irisciss the characteristic foatures of the cetal circuovale, (d) the hyponastific arteries, (e) the unbitical vein.

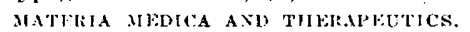

1. What is the physiglogic action of cocain? 2. What are the symptons of indism, and how prevented while continuing the

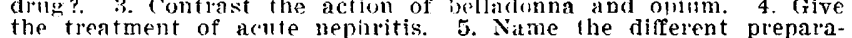
the treatment of acllte nepiritis. 5. Nathe the different prepara-
tions of mercury and their doses. G. Name three drugs whose thons of mercury and their doses. G. Nane three drugs whose action difters in promoting dillesis. Give an example of each. solium the toratment of the foilowing intesina parasites: (1) Tonia

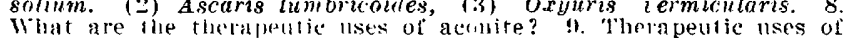
componnd jalop powder its composition and doses. 10. 1'thysiologic action of jaborandi; its therapeutic uses. ANATOMY.

1. Desclibe the differences brtween the sacrum of the male and that of the female. 2 . Glve the minute anatomy of the skin. 3 . What veins leturn the llood from the load and face? 4 . (ilve a divicions: make of the tritacial nerve, mentioning its pirincipal subdivio, (b) muscular connections, (c) nerve supply. (d) biood supply. 6. What are. the valvula conniventes and how are they formed? 7 . 6. What is a femoral hernia? Mention the covering of the same from without. inward. 8. Give the relations of the heart to adjacent organs and tisstles. 9 . Describe tle pancleas. 10. What is the
aldomen? Trescribe its boundaries, its reglons and parts included in each. Make a sketch. OBSTETRICS AXD gYNECOLOGY.

1. Define and give the patbilosy of: (a) l'elvic hematocele; (b) pelvic hematoma. Five treatment for each. 2. What are the factors in the production of pselitis in pregnancy? At what time
does it uccur, and which kidney is more often involved? 3 . Is the eclampsia in plecsnancy die to renal or extrareval conditions? What are the most rerent theories as to its canse? 4 . What are the varieties of fibroid tumors: (a) Signs and srmptoms? (b) The treatment for the hemorrbage. 5. Tesclibe the cause and mechan-
ism of (a) rotation and (b) expulsion of the head in the second stage of labor. f. Describe (a) hematophilla. (b) cenhal-hematomata. (c) meningocele. 7. Define Bandl's ring. Explain how it retards labor. 8 . Give the technic of the vartous methods of pelvi-
metry. 0 . What are the characteristics of a hydrosalninx? 10 . metry. O. What are the characteristics of a hydrosalninx? 10.
Discuss ophthalmia necnatorum and the practical importance of its plevention. SCRGERY.

1. Give s.ymptoms of sureical sbock and explain their significance. 2. Describe the vartous ways of arresting hemorrhage. 3. Discuss local anesthesia, and lescribe the technic of its application in some
major operation. 4. Describe the technie of ether narcosis. and give major operation. 4. Pescribe the technie of ether narcosis. and give centra-indications to the use of the dring. 5. Nescribe Allis' or
Pigeinw's method of reducing outward dislocation of the hip foint, Pigelow's method of reducing outward dislocation of the hip joint,
explaining the reason for each sten. f. Name the symptoms and explaining the reason for each sten. 6. Name the symptoms and signs which in ronr indsment would require immediate oneration in
a case of appendicitis. 7 . What historv and what present condition wonld lead you to advise operation in a latent or arrested case

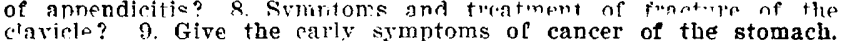
chariele? 9. Give the carly symptoms of cancer of the stomach.
10. Five the symptoms and signs of strnneulated inguinal hernia and describe a satisfactory operation for the condition. CHEMISTRY AND HYGIENE.

1. Name the portals of entry in tuberculosis. How is bovine tuberculosis transmitted to mankind? 2. Fire the formula for salt. What is its function in the animal economy? IIow is its presence domonstrated in thi lirine? 3. What are: (a) normal salts? (b) acid salts? (c) basic salts? (d) donble salts? 4. Do the various fruits of the market infect tie intestian canal? now wnmid roun hemoslolin. Name some of its nronelties. How is it changed to hemoglolin. Name some of its promelties. Iow is it changed to
orrhemostrin? Five in detril the best test for it. 6. What conditions shnuld confemn water for drinline nurposes? 7 . What is glycerin, butter, lecithin? Explain their relations to the fats. 8 . Wow is the most eommon poisonous compound of arsenic? How does it enter the svatem? Give srmptoms and treatment. 9 . What is mic acid? Mnes it nrcur free in the mine? What does its

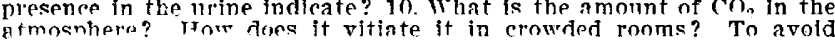
gtmosnhera? Ther foes it vitiate it in crowrded ronms? To avold
atmosnheric vitiation. hnw much space should be allowed occupant atmosnheric vitiatinn. hnw mis
of dormitories and hospltals?

Colorado July Report.-Dr. S. D. Van Meter, secretary of the Colorado State Board of Medical Fxaminers. reports the written and oral pxamination held at Denver. Julv 3. 1906. The number of subjects examined in was 8 ; total number of questions askel. So; perentage required to pass, 70 . The 